\title{
ECO-INVESTMENTS - LIFE CYCLE ASSESSMENT OF DIFFERENT SCENARIOS OF BIOMASS COMBUSTION
}

\author{
EKOINWESTYCJE - OCENA CYKLU ŻYCIA \\ DLA RÓŻNYCH SCENARIUSZY SPALANIA BIOMASY
}

\begin{abstract}
The article presents the results of life cycle assessment of different scenarios of biomass use to produce energy in a selected company. The study is made on the case of Lesaffre Polska S.A. and its facility in Wolczyn which is one of the most modern biomass plants in Central Europe. The company is one of the leaders of using the environmental criteria in its strategic decision-making. Its goal is to avoid any waste and to form its own circular business system. One of its recent investments is a biomass fired steam boiler that uses agricultural and woody biomass to produce energy. Previously, biomass was sold to power plant and co-fired with coal. The scope of the paper is to assess the actual change in the environmental impact of biomass use in the Wolczyn facility. For that purpose, the life cycle assessment is used with the ReCiPe endpoint indicator. The assessment is based on the comparison of two scenarios: one assuming the biomass combustion in a new boiler, and the second one, assuming co-firing biomass with coal. The results of the study show that the investment is making a significant difference as far as the overall environmental impact is. Through avoiding the co-firing related emissions the company makes a big step ahead towards the decrease of their environmental impacts. The analysis shows that the significant impact in the co-firing scenario is posed in such categories as fossil depletion, climate change with impacts on human health and on ecosystems, particulate matter formation and agricultural land occupation. In the biomass combustion scenario, the above categories are complemented with metal depletion, natural land transformation, urban land occupation and human toxicity categories but with 4 times decrease of the overall impact. The study also shows that the change of the combustion system makes the most significant difference, while all the other factors, like biomass cultivation and processing, biomass transport have much lesser impact.
\end{abstract}

Keywords: biomass combustion, life cycle assessment, energy crops, Lesaffre Polska S.A.

\section{Introduction}

The vast majority of energy is generated with traditional methods of fossil fuels firing, such as oil, coal and natural gas, and altogether it covers $86 \%$ of the global energy demand [1]. The biggest problem related to this traditional way lies within the scarcity of the fuels resources. Therefore, it is necessary to use an alternative way of energy generation by applying renewable energy sources [2]. The situation is no different in Poland, where only

\footnotetext{
${ }^{1}$ Faculty of Management, Czestochowa University of Technology, al. Armii Krajowej 19B, 42-200 Częstochowa, Poland, phone +48 3432504 84, email: tomaszn@zim.pcz.pl, agnieszkaociepa22@wp.pl

*Corresponding author: agnieszkaociepa22@wp.pl
} 
a few percent of energy comes from renewable sources. The objective is to increase the share of "green" energy to $14 \%$ by 2020 . Otherwise, the threat of the EU fines imposed on Poland becomes truly possible [3]. High share of agriculture in Polish economic activities and in land use, good soil conditions, decent forestation, and sound climate conditions are promising for the development of the biomass based energy generation. Biomass is the oldest and most widely used renewable energy source. Biomass is a category that includes all the organic matter that exists on Earth, along with plant and animal originating substances [4-6]. For the purposes of energy generation, the most often used types of biomass include: wood and its residues, waste wood, straw, cropped energy plants, agricultural products, by-products and waste [1]. Moreover, biomass use for energy generation purposes could be easily done on both large and small scale, by introducing biomass in a fuel mix to traditional coal fired boilers or by installing new boilers dedicated to biomass only. The proper use of biomass brings a lot of different benefits:

- environmental (reduction of emission of gases and dust into the atmosphere, reducing the consumption of fossil fuels),

- economic (increasing the energy security of the country),

- $\quad$ social (the chance to expand the local labor market) [7].

We use Lesaffre Polska SA and its facility in Wolczyn as an example of a company that develops its biomass use scheme for the purposes of energy production. In that facility the company cultivates and utilizes biomass energy crops to obtain the "green" energy. The object of our analysis was the newly constructed biomass-fired steam boiler. The Wolczyn facility, and especially its biomass system are considered as ones of the most modern and the least energy-intensive in Central Europe. The objective of this article was to assess the new biomass use scheme, with biomass combustion in steam boiler, in comparison to the old scheme, with biomass co-firing with coal. For that purpose, a simplified life cycles assessment of biomass use was made.

\section{The potential of the use of agricultural biomass as a renewable energy source}

Biomass covers a wide range of products, by-products and waste streams from forestry and agriculture as well as municipal and industrial waste streams. According to the EU adopted definition biomass is "...the biodegradable fraction of products, waste and residues from agriculture (including vegetal and animal substances), forestry and related industries, as well as the biodegradable fraction of industrial and municipal waste..." [8]. Biomass, thus, includes trees, arable crops, algae and other plants, agricultural and forest residues, effluents, sewage sludge, manures, industrial by-products and the organic fraction of municipal solid waste. According to the forecast of the Polish Energy Policy until 2030 the solid biomass is to play the most significant role in the process of the increase of the renewable energy sources use [9]. Biomass should be considered as a main alternative for coal that dominates current fuel mix in Poland. With respect to the types of elements included, coal and biomass are similar, but the quantitative structure of the basic elements is different. Woody biomass includes, on average, four times more oxygen than coal, two times less carbon and significantly less sulphur and nitrogen. One of its advantages is zero balance of carbon dioxide emissions in the combustion process, due to smaller amounts of ashes and chlorine and to its use in the photosynthesis process. The main disadvantage of biomass is its high and variable moisture and low heating value [10]. Also, it includes 
higher amounts of alkaline metals, calcium and phosphorus that contribute to the corrosion acceleration during its direct combustion. Moreover, biomass lower density causes the need of providing bigger warehousing space and transport volumes [11,12]. Currently, the practice of co-firing coal and biomass in power and heat plants is quite common. It is due to the financial soundness and technical efficiency of this approach to energy generation from biomass [13-15].

The possibilities of using biomass are shown on Figure 1. In order to meet the demand, the process of biomass plants cultivation is necessary. Energy crops can be divided into the following groups:

- Grass plants (switchgrass, miscanthus),

- Herbal plants (Sida hermaphrodita, artichoke),

- Wooden plants (willow, poplar).

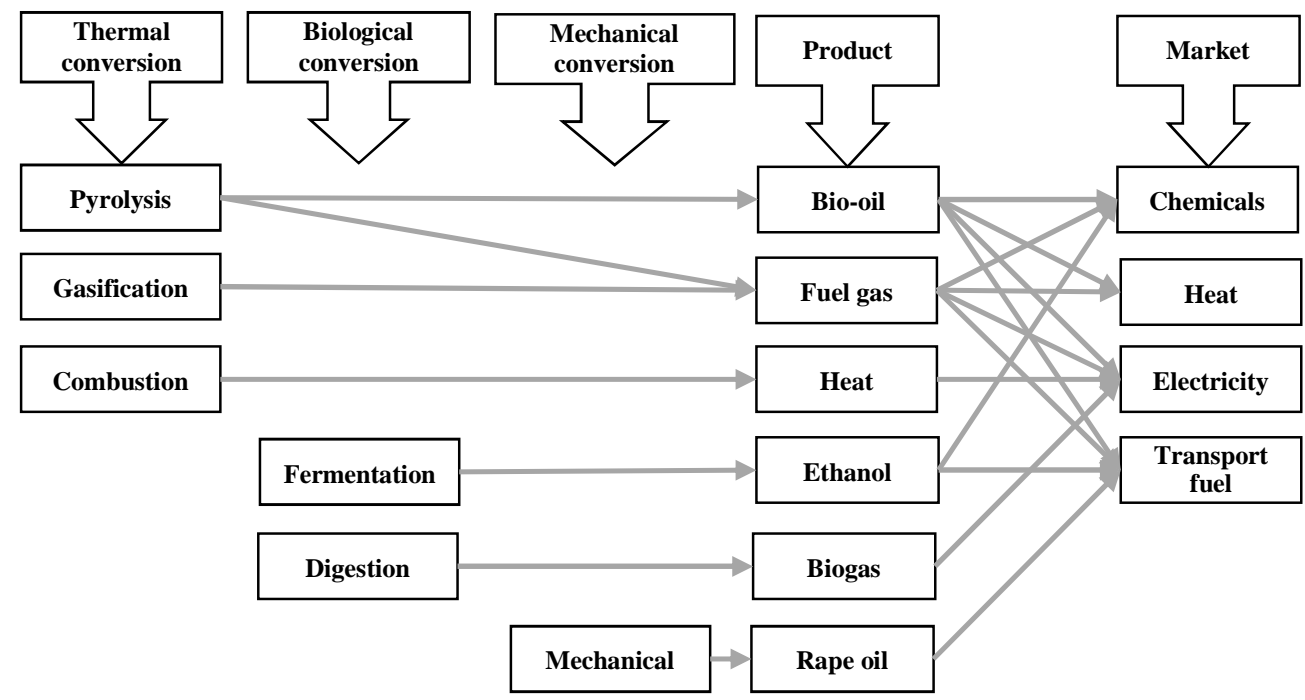

Fig. 1. Diagram of possible use of plant materials for energy purposes [8]

In order to use biomass for industrial scale energy generation, some basic requirements must be met, including high yield, high content of dry mass, resistance to pests and climate conditions, high heat value $[16,17]$. After harvesting, energy plants are processed (drying, powdering and pressing) to form pellets.

The most influential natural environment-related factors for biomass yield are climate conditions and soil. Energy plants can be cultivated on different soil classes, but preferences should be to use marginal class soils with difficult use conditions [18]. In Poland, the areas available for biomass cultivation in the horizon of the year 2020 are estimated to reach up to 4.1 billion hectares. In the Opole region the potential of biomass harvesting is very high due to high share of agricultural land use $62 \%$ and high forestation $27 \%$. Almost the entire area is suitable for energy plants cultivation [19]. 


\section{Materials and methods}

\section{Life cycle assessment use for measuring environmental impact of biomass use}

Life cycle assessment (LCA) is one of environmental management tools that could significantly contribute to the identification of environmental impacts related to biomass use. The key assumption behind the LCA method is the life cycle approach to define the product system and to include all of its life cycle phases in the assessment. Therefore, such an assessment refers to pre-manufacturing (designing, extraction of raw materials and their prefabrication), manufacturing (production and its preparation, production logistics) and post-manufacturing phases (sales logistics, use and end of life disposal and value recovery). A set of information resulting from LCA use enables environmentally conscious decision making in companies, especially if the environmental impacts are at stake and the approach taken towards them could be used as a bargaining bid in negotiations with different stakeholders groups.

Environmental impacts in LCA are measured by midpoint and endpoint indicators. Midpoint indicators reveal life cycle share in different categories of environmental impacts while endpoint indicators convert them into damage categories [20]. The values of indicators are calculated on the basis of different flows in the life cycle, including material, energy, emission and waste flows. LCA, as a part of a wider environmental management system and decision support, could be used to identify and assess environmental aspects in wide range of forms, starting from initial environmental review up to detailed monitoring and continuous improvement systems in organizations. The default scale of assessment whole life cycle of the product - could be easily adjusted to selected phases or stages. Since LCA is widely discussed in the literature, the paper is focused on its use with specific range and scope (as explained below). Full description of the LCA method and its application procedure could be found elsewhere [21,22].

\section{The assessments of biomass use a review of previous studies}

Biomass use to produce energy has been due to many scientific and applicative investigation throughout last decades. The dominant topics were its economic and environmental performance within energy production systems, considered both from micro and macro scales.

The status of biomass use for energy production in Europe is an objective of Lopez-Bellido et al. research [23]. The main focus is on agricultural potential of biomass use in the context of different energy carriers. The scope of analysis is very broad and covers also technical, market and environmental issues of biomass use for energy production purposes. Important aspect of the analysis is the relationship of biomass harvesting to food crop farming and possible compromises between the two that should be made in order to maintain the efficiency and effectiveness of both sectors [23].

Khorshidi et al. analyze the functioning of biomass co-firing systems with relation to $\mathrm{CO}_{2}$ capture and storage installation use. The parameters influencing technical and economic efficiencies of facilities that are taken into account include biomass quality and structure of its supply [24]. For similar purposes, Schakel et al. use LCA [25]. Their focus is on the biomass combustion vs. co-firing variants. As a result of their assessment the system of biomass co-firing with carbon capture and storage installation is named as a potentially the most sustainable one [25]. Kabir and Kumar [26] also use LCA but for 
complex assessment of biomass co-firing system with a focus on its technical parameters, such as biomass origins, its disintegration process and co-firing conditions.

Similar scope of analysis was used by Andric et al. but with a different method, namely carbon footprint, which should be considered as a specific single LCA [27]. Goglio and Owende has made simplified LCA for small scale electricity generation with agricultural biomass. They have used a number of simple impact indicators such as energy use, energy output input ratio and $\mathrm{CO}_{2}$ emissions. They also have made sensitivity analysis of their results that led them to conclusion that high importance factors in willow based biomass system are a drying process, fertilizers types and application procedures and installation type. They have also referred to transport issues and indicated that in the case of small distance transportation of biomass its share in overall environmental impact could be rather neglected [28].

Nian uses synchronized process chain approach to perform comparative analysis of interconnected energy systems that are based on woody biomass and coal. Nian formulates critical remarks toward common practice of assuming woody biomass carbon neutrality, in the case of its use as a stand-alone fuel. Instead, he points out that its true potential lies within the replacement of coal in co-firing installations. Much effort is also taken to define system borders while biomass fired and co-fired installations are concerned [29]. Murphy et al. uses LCA to optimize supply chain in biomass based energy generation systems. They show that biomass dedicated co-generation systems have much greater potential in achieving environmental goals than the biomass co-firing systems. The important feature of biomass system that is investigated in the paper is the diversification of biomass sources and plants (Miscanthus giganteus and willow). They use Global Warming Potential as a life cycle impact assessment method that leads to the estimation of greenhouse gases reduction potential [30].

Dzikuc and Piwowar use LCA to assess the environmental performance of biomass co-firing in Poland on the basis of selected power plants. They supplement LCA indicators with economic analysis in order to give more complex picture of biomass co-firing with coal [31].

Country fuel mix could be also assessed with LCA. Tonini and Astrup use LCA to assess the perspectives of environmental impacts of energy system in Denmark that has significant share of biomass in fuel mix. They also indicate key impact categories related to biomass combustion, which are change in natural land use, use of fertilizers and transport related emission of $\mathrm{NO}_{\mathrm{x}}$ [32]. In further research, Tonini et al. indicate that in the case of agricultural biomass (including willow and Miscanthus giganteus) the significant environmental effects could be achieved with its direct combustion only, and not with its transformation to biofuels or biogases and latter indirect use [33]. Similar research is made by Gonzales-Garcia et al. for single type of biomass, namely willow. They compare biomass use to generate electricity and to ethanol production. As a result of their analysis, they show that, on the one hand, both analyzed systems have significant advantages over conventional energy systems. On the other hand, the results show that both systems include processes that should be optimized with regards to their environmental impacts with the use of the best practices and new knowledge in the field. The results do not definitely indicate which one of the investigated systems is more environmentally sound. Instead, they show that the specificity of environmental impacts should be always assessed individually, bearing in mind whole energy systems, their overall impacts but also the structure of these impacts [34]. 


\section{The scope of Lesaffre Polska S.A. activities}

The history of producing yeast by Lesaffre is dating back to 1893. The French group Lesaffre is a family company founded in France back then and has grown over 120 years to multinational corporation that currently operates in more than 180 countries on 5 continents. Its beginning in Poland dates back to the last decade of the previous age but in 2007, the company became a joint stock company and took the name Lesaffre Polska S.A. Currently its headquarters and manufacturing facility are located in Wolczyn in the Opolskie voivodship. The Group has a wide range of products of industrial fermentation: yeast ferments and derivatives such as bread improvers. The company's offer includes also organic fertilizers: Vinassa, Potavin and potassium extract, the recovery of which is associated with the production of yeast. With its basic products and the agricultural use of waste Lesaffre Polska S.A. makes good effort to follow the sustainability principle [35].

Their policy of making micro version of round economy in their manufacturing processes has been their trademark ever since. Their efforts towards environmental performance optimization have also led them to the acquisition of ISO 14001 certificate, to the implementation of Cleaner Production Program and obtaining Cleaner Production awards for their industrial installations. Their commitment to the sustainability issues is also a matter of their internal Policy on Corporate Safety, Quality and Environment [35].

While orientating their business towards closed loops the company has also introduced energy crops as one of their side products. The cultivation of energy crops and their use in the enterprise is an innovative and environmentally friendly operation. Using a number of agricultural areas in the neighborhood of the facility the company established energy plantations. Additional environmental activities related to the cultivation of energy crops for the facility, confirm that orientation on sustainable solution is not only a routine procedure in an experienced multinational company but can be considered as an innovative and pioneering activity [35].

\section{Characteristics of energy crops used by the company}

Energy crops are plants obtaining a significant growth of biomass in a short time and with high calorific value. Wolczyn facility uses the following types of agricultural biomass: Miscanthus giganteus approx. 2 ha, willow approx. 20 ha, reed canary grass 35 ha, Panicum virgatum approx. 35 ha. As shown in Table 1, plants are characterized by high yield which could be obtained per ha, up to $15-20 \mathrm{Mg} / \mathrm{ha}$ (willow, Miscanthus giganteus) and the relatively high energy value up to approx. 16-19 GJ/kg (Miscanthus giganteus, Panicum virgatum) [36].

While introducing energy crops to business processes the cost of plantation establishment should be taken into account. Panicum virgatum and canary reed grass have rather low costs of planting, while miscanthus and willow have rather moderate or even high costs. Financial engagement is also related to protection against pests and diseases. For all interchangeable plants, treatments are necessary to obtain the greatest yields. It should be emphasized that the cultivated biomass plants are characterized on average by low requirements of soil and climatic conditions of the region are sufficient for these crops.

Agro-technical activities related to the establishment of the plantation and its maintenance and collection of biomass are fully mechanized. Some studies have shown that the type of fertilizing has an influence on the growth of biomass and a calorific value of 
plants [37]. The practice of Lesaffre Polska S.A. is to use wastewater from the production of yeast and organic products as a fertilizer for biomass crops. It allows for the use of waste substances and leads to obtain high yields per hectare. In the end, it brings financial benefits for the company [35].

Table 1

Characteristics of energy plants cultivated in Wolczyn facility

\begin{tabular}{|c|c|c|c|c|}
\hline Plant & Description & $\begin{array}{c}\text { Specific } \\
\text { requirements } \\
\text { for soil }\end{array}$ & $\begin{array}{c}\text { Crop (dry } \\
\text { mass) } \\
\text { [Mg/ha] }\end{array}$ & $\begin{array}{c}\text { Energy value } \\
\text { [GJ/kg] }\end{array}$ \\
\hline Willow & $\begin{array}{c}\text { Shrub reaching a height of 5 m and } \\
\text { a diameter of several centimeters. It comes } \\
\text { from Eurasia }\end{array}$ & $\begin{array}{c}\text { high soil } \\
\text { moisture }\end{array}$ & $15-20$ & $6-9$ \\
\hline$\frac{\text { Reed canary }}{\text { grass }}$ & $\begin{array}{c}\text { It is the perennial plant species. It reaches } \\
\text { a height of 3 meters and is strongly leafy. } \\
\text { It comes with our climate zone }\end{array}$ & any soil & $7-10$ & $13-15$ \\
\hline $\begin{array}{c}\text { Panicum } \\
\text { virgatum }\end{array}$ & $\begin{array}{c}\text { Hard perennial grass growing in clumps. } \\
\text { It can reach a height of 1.3-2.2 m. It comes } \\
\text { from North America }\end{array}$ & any soil & $7-9$ & $15-17$ \\
\hline $\begin{array}{c}\text { Miscanthus } \\
\text { giganteus }\end{array}$ & $\begin{array}{c}\text { Grass grows in clumps reaching a height } \\
\text { of 2.0-4.0 m. The diameter of shoots ranges } \\
\text { from } 1 \text { to } 3 \text { cm. It comes from Asia }\end{array}$ & any soil & $13-16$ & $17-19$ \\
\hline
\end{tabular}

Source: Own study based on materials from the company

In 2013, modern steam boiler for biomass was built at the company. The boiler uses a mixture of:

- Woody biomass $(80-90 \%)$

- Agricultural biomass (10-20\%).

Table 2 presents average yearly fuel mix for steam boiler. Woody biomass consists of forest residues, wood chips and sawmill biomass, while agricultural biomass of willow chips and straw from energy crops. The boiler and incineration process meet the requirements of environmental protection. The cleaned (dust-free) exhaust gases are discharged into the atmosphere. Emissions do not exceed the permissible emission standards and are consistent with the requirements of the permit No. ROS.6224.4.2011.EU for gas and dust, issued by the Prefect of Kluczbork on 6th February 2012 [36].

Table 2

Fuel mix for biomass boiler (10\% agricultural biomass)

\begin{tabular}{|c|c|c|}
\hline Fuel type & $\begin{array}{c}\text { Yearly use } \\
{[\mathbf{M g} / \mathbf{y e a r}]}\end{array}$ & $\begin{array}{c}\text { Share in total use } \\
{[\%]}\end{array}$ \\
\hline Miscanthus giganteus & 35 & 0.4 \\
\hline Willow & 370 & 3.8 \\
\hline Reed canary grass & 280 & 2.9 \\
\hline Panicum virgatum & 280 & 2.9 \\
\hline Woody biomass & 8685 & 90.0 \\
\hline Total & 9650 & 100.00 \\
\hline
\end{tabular}

Source: Own study based on materials from the company

Biomass is characterized by relatively low density of the raw material, hindering the transportation and storage, and therefore, thanks to the construction of on-site biomass, 
steam boiler can use the biomass directly and avoid its additional transport and storage. According to the company declarations, the advantages of growing and using energy crops on the site are not only for economic reasons, but also to improve the company's image in the eyes of customers and suppliers as well. These activities are conducive to achieve the objectives, set in the National Environmental Policy for reducing emissions, that affect the climate change.

\section{Results}

\section{Life cycle inventory of biomass use scenarios}

The practice of biomass use to produce energy has been recently changed in the Wolczyn facility. The major changing factor is the installation of biomass fired steam boiler that enabled the use of the whole amount of biomass in the facility. This change serves as a verification point of the environmental impacts of the facility that should be reduced as declared by the company. According to these circumstances two scenarios have been formulated:

- Scenario 1 (historical) - remaining biomass sale to power plant and its co-firing with coal

- $\quad$ Scenario 2 (present) - biomass combustion in steam boiler

Scenario 1 describes the historical situation of selling agricultural biomass remains to nearby power plant. Scenario 2 presents current situation when all the biomass is used on-site and its remains are burned in steam boiler. In order to achieve economic and technical efficiency, and to reach desirable energy output, agricultural biomass is heavily supplemented with woody biomass that is purchased on the market.

In our study, the functional unit is defined as one year energy production equivalent for two variants of biomass use as defined in two scenarios. Taking up such a perspective of defining functional unit enables comparison of two scenarios with regard to overall environmental effects related to company activities. In scenario 1 agricultural biomass and coal are co-fired to produce energy, while in scenario 2 it is agricultural and woody biomass. In both cases it is $41850 \mathrm{MWh}$, which is yearly energy production equivalent in Wolczyn and a part of electricity production in the Opole power plant.

Impact factors in life cycle with regard to scenarios 1 and 2

\begin{tabular}{|c|c|c|}
\hline Life cycle impast factors & $\begin{array}{c}\text { Scenario 1 } \\
\text { Co-firing with coal }\end{array}$ & $\begin{array}{c}\text { Scenario } 2 \\
\text { Combustion in steam boiler }\end{array}$ \\
\hline Biomass harvesting & Agricultural biomass harvesting & $\begin{array}{c}\text { Agricultural biomass harvesting } \\
\text { Purchase and collection of woody biomass }\end{array}$ \\
\hline $\begin{array}{c}\text { Transport - biomass } \\
\text { collection }\end{array}$ & $\begin{array}{l}\text { Tractor with trailer transport } \\
\text { of agricultural biomass from } \\
\text { fields (about } 20 \mathrm{~km} \text { ) }\end{array}$ & $\begin{array}{c}\text { Tractor with trailer transport of agricultural } \\
\text { biomass from fields (on average about } 20 \mathrm{~km} \text { ) } \\
\text { Lorry truck transport of woody biomass from } \\
\text { suppliers (on average about } 50 \mathrm{~km} \text { ) }\end{array}$ \\
\hline Biomass preparation & Chopping, drying and storage & $\begin{array}{l}\text { Chopping, drying and storage } \\
\text { Internal transport to boiler (with conveyor belt) }\end{array}$ \\
\hline $\begin{array}{l}\text { Transport - biomass } \\
\text { distribution }\end{array}$ & $\begin{array}{l}\text { Lorry truck transport to power } \\
\text { plant } 50 \mathrm{~km}\end{array}$ & - \\
\hline Energy production & $\begin{array}{l}\text { Co-firing with coal to produce } \\
\text { electricity }\end{array}$ & Combustion to produce heat \\
\hline
\end{tabular}

Source: Own study based on materials from the company 
In the following step the description of the investigated scenarios includes the sources of its possible impact on the environment. As shown in Table 3, several phases and processes in the life cycle of biomass are diversifying the impacts of two scenarios. With regard to logistic issues, major differences lie within the transportation of woody and agricultural biomass in the phases of biomass collection and distribution. The differences are depictured by different transport means use (tractor with trailer and truck) and the values of mass and distance variables.

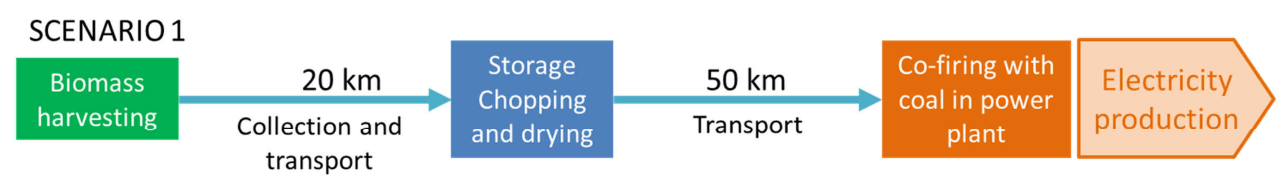

\section{SCENARIO 2}

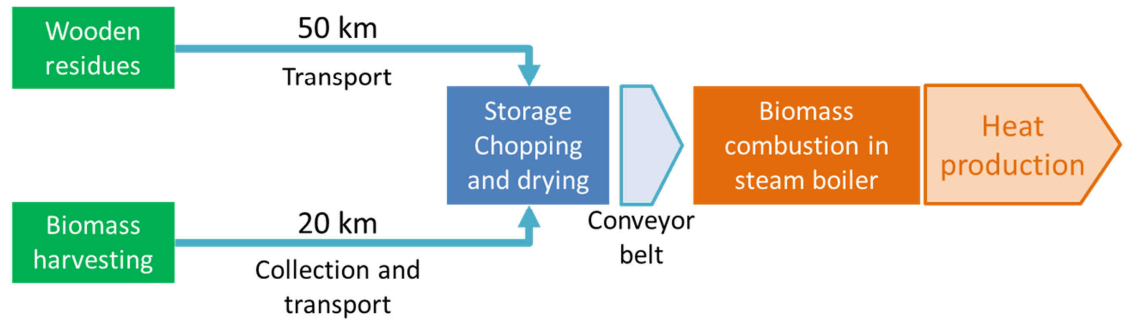

Fig. 2. Life cycle flow for scenarios 1 and 2. Source: Own study based on materials from the company

Impact factors inventory with regard to $1-2$ scenarios

\begin{tabular}{|c|c|c|}
\hline Impact factor & Scenario 1 & Scenario 2 \\
\hline \multicolumn{2}{|c|}{ Biomass harvesting and purchase $[\mathrm{Mg}]$} & 35 \\
\hline Miscanthus giganteus & 35 & 370 \\
\hline Willow & 370 & 280 \\
\hline Reed canary grass & 280 & 280 \\
\hline Panicum virgatum & 280 & 8685 \\
\hline Woody biomass & 0 & 868500 \\
\hline \multicolumn{2}{|c|}{ Transport [Mg. km] } \\
\hline Biomass collection and supply $^{1}$ & 48250 & 0 \\
\hline Biomass distribution $^{2}$ & 241250 & 41850 \\
\hline
\end{tabular}

${ }^{1}$ The collection and delivery of agricultural biomass is assumed to be made with tractor with trailer only on the distance of $20 \mathrm{~km}$ on average, while wooden biomass is supplied with medium size trucks on $50 \mathrm{~km}$ distance on average, ${ }^{2}$ The distribution of biomass is assumed to be made with medium or big size freight trucks on the distance of $50 \mathrm{~km}$.

Figure 2 presents the simplified scheme of life cycle flows in both of the scenarios considered. We can observe that transport efforts are simply moved from one life cycle phase to another. Due to technical specification of steam boiler, the fuel mix for scenario 
2 needs to be composed of woody and agricultural biomass. The ratio between the two types of biomass ( $90 \%$ of woody biomass to $10 \%$ of agricultural biomass) impose the incremental purchases of woody biomass and, as a consequence its transport to the facility. The composition of fuel mix, transportation needs and combustion effects are presented in detail in Table 4.

Comparing the two scenarios with reference to transport only, we could observe much bigger company invoked transport in scenario 2 . We have to notice that scenario 1 bears also transport efforts that are not taken into account here. Namely, it is transportation of coal from mines and re-sellers to power plant. Due to the lack of information on exact cofiring ratio between the two fuels and major transport variables (average distance and transport means), it is not included in the assessment. The results are biased by omitting these data, but certainly, coal transport is not a company dependent variable, and therefore is outside the scope of the paper.

Biomass cofiring / combustion was calculated on the basis of data from Table 5.

Table 5

The following factors are used to calculate generated energy

\begin{tabular}{|c|c|c|c|}
\hline Fuel & $\begin{array}{c}\text { Heat value } \\
{[\mathbf{M J} / \mathbf{k g}]}\end{array}$ & $\begin{array}{c}\text { Conversion factor } \\
{[\mathbf{k W h} / \mathbf{k g}]}\end{array}$ & Source \\
\hline Miscanthus giganteus & 19.1 & 5.31 & {$[38]$} \\
\hline Willow & 18.1 & 5.03 & {$[38]$} \\
\hline Reed canary grass & 20.3 & 5.64 & {$[38]$} \\
\hline Panicum virgatum & 17.2 & 4.69 & {$[38]$} \\
\hline Woody biomass & 15.3 & 4.25 & {$[38]$} \\
\hline
\end{tabular}

Source: Own study based on materials from the company

\section{Life cycle impact assessment}

Methodology of LCA enables free adoption of impact assessment methods to the goals and specificity of the assessment. In this study we use the ReCiPe (the method for LCIA has been given the name ReCiPe 2008, as it provides a recipe to calculate life cycle impact category indicators. The acronym also represents the initials of the institutes that were the main contributors to this project and the major collaborators in its design: RIVM and Radboud University, CML, and PRe). The selection of this method is related to the reference of its allocation and calculation default setups to Europe that enable reliable assessments for Poland and common practices in industry, agriculture and transport. Since the ReCiPe method is based on ecoinvent 3.0 database framework for life cycle flows, also the database is used to cover them. ReCiPe endpoint indicator is a type of single weighted indicator, expressed in points $\mathrm{Pt}^{2}$ that enables straightforward interpretation. The ReCiPe single score indicator is calculated on the basis of three categories of damage indicators [38]:

- Damage to human health (expressed in disability-adjusted loss of life years),

- Damage to ecosystem diversity (loss of species during a year),

- Damage to resources availability (increased costs).

\footnotetext{
${ }^{2}$ Value of $1 \mathrm{Pt}$ is calculated through dividing total environmental impact in Europe by number of citizens and multiplicated by 1000 (scale factor); in other words its value is one-thousandth of yearly environmental load accounted for single Europe citizen
} 
Damage category indicators are calculated from the following impact category indicators $[38,39]$ :

- Climate change (Human Health impact)

- Ozone depletion

- Human toxicity

- Photochemical oxidant formation

- Particulate matter formation

- Ionising radiation

- Climate change (Ecosystems impact)

- Terrestrial acidification

- Freshwater eutrophication

- Terrestrial ecotoxicity

- Freshwater ecotoxicity

- Marine ecotoxicity

- Agricultural land occupation

- Urban land occupation

- Natural land transformation

- Metal depletion

- Fossil depletion

The values of impact category indicators are calculated on the basis of material, energy, waste and emission flows in life cycle with the use of appropriate allocation mechanisms. The allocation mechanisms are not interfered with and are default in SimaPro software as proposed by Goedkoop et al. [38], the actual designers of the method. The ReCiPe method calculates emissions and impact levels in a given cycle (step 1), assesses its impact on the environment and human beings expressed in diversified impact category indicators (step 2) and its aggregation to damage category indicators and single score indicator (step 3). The method enables automatic allocation of specific emissions and impacts to appropriate damage and impact categories.

Figure 3 presents the flow chart of biomass use life cycle in two investigated scenarios. Thickness of arrows indicated the share of given process in the value ReCiPe endpoint single score indicator. Additionally, these shares are shown also in appropriate cells. The basic difference between environmental impacts of the scenarios is the biomass combustion process. In scenario 1, biomass is co-fired with coal and it is highly impacting its crucial share in the environmental impacts $(96.7 \%$ share in an overall impact). Since it is hardly possible to distinguish biomass related emissions when co-fired with coal, the whole impact should be taken into account. The significance of the biomass combustion scenario is also underlined by the share of agricultural and woody biomass harvesting, which accounts for $2.55 \%$ in scenario 1 , and $45.4 \%$ in scenario 2 . Analogical changes could be observed for transportation share in both scenarios. It is worth mentioning that the impacts of different types of biomass in their harvesting and combustion phases are significantly diversified as well. This diversification is affected by the harvesting requirements and procedures for different types of biomass, its calorific values, preparation processes intensity and combustion process characteristics.

Table 6 presents ReCiPe impact indicators for the investigated scenarios. The indicators are normalized. The biggest difference between the scenarios is again the overall impact. Scenario 1 has almost four times bigger impact on environment then scenario 2. 


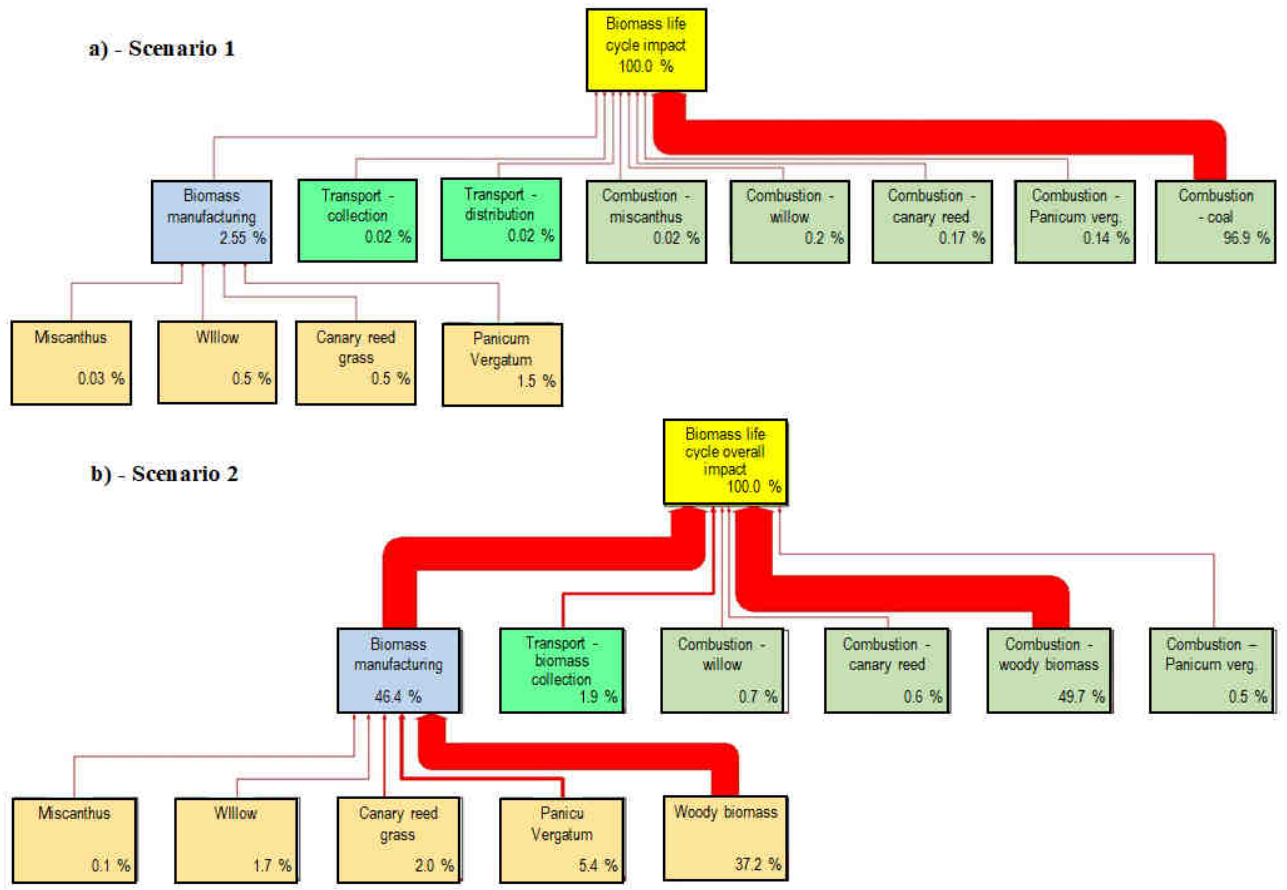

Fig. 3. Share of key processes in overall ReCiPe endpoint indicator for biomass life cycle impact for: a) scenario 1 and b) scenario 2 . Source: Own study based on materials from the company

Table 6

Values of endpoint ReCiPe impact category indicators after normalization with regard to scenarios 1 and 2

\begin{tabular}{|c|c|c|}
\hline Impact category & Scenario 1 & Scenario 2 \\
\hline Climate change Human Health & 2842.65 & 361.88 \\
\hline Ozone depletion & 0.06 & 0.04 \\
\hline Human toxicity & 24.52 & 31.72 \\
\hline Photochemical oxidant formation & 0,17 & 0.06 \\
\hline Particulate matter formation & 811.12 & 199.26 \\
\hline Ionising radiation & 0.28 & 0.25 \\
\hline Climate change Ecosystems & 1795.43 & 228.51 \\
\hline Terrestrial acidification & 6.93 & 1.35 \\
\hline Freshwater eutrophication & 1.17 & 0.23 \\
\hline Terrestrial ecotoxicity & 0.61 & 1.06 \\
\hline Freshwater ecotoxicity & 0.02 & 0.00 \\
\hline Marine ecotoxicity & 0.01 & 0.01 \\
\hline Agricultural land occupation & 291.33 & 1363.30 \\
\hline Urban land occupation & 21,42 & 32.76 \\
\hline Natural land transformation & 13.96 & 35.35 \\
\hline Metal depletion & 46.81 & 63.23 \\
\hline Fossil depletion & 5830.53 & 591.03 \\
\hline Total & 11687.03 & 2910.04 \\
\hline
\end{tabular}

Source: Own study based on materials from the company 
As shown in Table 6 it is caused by the coal use and related emission in its co-firing with biomass. In the case of scenario 1 , there are only five impact categories with share in single score indicator bigger than $1 \%$. These are: fossil depletion, climate change with impacts for human health and for ecosystems, particulate matter formation and agricultural land occupation. In scenario 2, apart from these categories, also metal depletion, natural land transformation, urban land occupation and human toxicity impact categories exceed the $1 \%$ share threshold. We can also observe a significant decrease of combustion related impacts (fossil depletion, climate change and particulate matter formation) and an increase of harvest related impacts (land use and transformation, metal depletion).

\section{Discussion and conclusions}

\section{Interpretation}

To complement the assessment results also sensitivity analysis is performed in order to find possible sources of impact changes within the biomass use life cycle. The key discretionary variables are identified as: biomass structure and transportation routes. The reason behind omitting the remaining variables (biomass processing and combustion) are related to current technological infrastructure status in the facility. Additionally, both of the omitted variables are highly dependent on the biomass structure and, therefore, their quantitative aspects are in fact considered. All the changes are considered for scenario 2 since it is currently used in the facility. The sensitivity analysis has taken into account a $10 \%$ increase of the selected type of agricultural biomass and a $10 \%$ increase of transportation demand with the collection and supply of biomass. Table 7 presents the results of sensitivity analysis as expressed in the selected ReCiPe impact category indicators. Subsequent columns show the overall impact of biomass use life cycle but with the assumed $10 \%$ increase of one variable that is indicated in the column title. For example, column titled MG (Miscanthus giganteus) shows how the overall impact (row: total) and category impacts would change if the volume of miscanthus used in fuel mix was increased by $10 \%$. The actual impact in scenario 2 is shown in the last column. Table 7 refers to the impacts that exceeded $1 \%$ threshold in the overall impact of scenario 2 life cycle. Last row, for a change, summarizes all the categories (also those not shown here). In Table 6 , the columns showing the change of impacts caused by the $10 \%$ increase of certain factors should be referred to the last column with the actual impact of scenario 2 . Also, columns should be compared with one another in order to capture the influence of certain factors on overall and specific impacts. For example, we could observe that assumed changes contribute to the increase of impacts in a climate change considered with respect to effects for human health. But the impacts of $10 \%$ changes for miscanthus and willow are hardly noticeable (impact increase of 0.01 and 0.04 points, respectively), while for canary grass, Panicum virgatum and, most of all, for transport routes are more significant $(0.3 ; 0.23 ; 2.74$ points, respectively).

As we could observe, none of the changes would either significantly impact the overall environmental performance or the selected impact categories. Only the changes within transportation routes have the least noticeable impact. On the contrary, the changes within the numerical structure of biomass types would not significantly affect the overall impacts. Perhaps, it would be advisable to verify whether switching to one type of biomass only would significantly influence the overall or specific impacts, but for the moment, it is not an option for the company, since the biomass is not only used for energy production 
purposes, and its diversification has much deeper justification within the crop shifting and harvesting sustainability issues. On the other hand, environmental optimization in transport, especially with focus on route optimization, fuel use decrease and emission standards increase for company fleet could bring some important effects.

Table 7

Sensitivity analysis with regard to $10 \%$ share increase of factors in scenario 2

\begin{tabular}{|c|c|c|c|c|c|c|}
\hline & \multicolumn{5}{|c|}{ 10 \% increase factor } & \multirow{2}{*}{ S2 } \\
\hline Impact category & MG & W & SCG & PV & TR & \\
\hline Agricultural land occupation & 1363.33 & 1363.69 & 1363.64 & 1364.64 & 1363.78 & 1363.30 \\
\hline Fossil depletion & 591.03 & 591.11 & 591.55 & 591.43 & 597.18 & 591.03 \\
\hline Climate change Human Health & 361.89 & 361.93 & 362.18 & 362.11 & 364.62 & 361.88 \\
\hline Climate change Ecosystems & 228.51 & 228.53 & 228.69 & 228.65 & 230.24 & 228.51 \\
\hline Particulate matter formation & 199.26 & 199.27 & 199.41 & 199.33 & 200.93 & 199.26 \\
\hline Metal depletion & 63.24 & 63.25 & 63.32 & 63.30 & 64.69 & 63.23 \\
\hline Natural land transformation & 35.36 & 35.43 & 36.11 & 35.98 & 35.44 & 35.35 \\
\hline Urban land occupation & 32.76 & 32.76 & 32.76 & 32.76 & 32.91 & 32.76 \\
\hline Human toxicity & 31.72 & 31.72 & 31.73 & 31.72 & 31.89 & 31.72 \\
\hline Total & 2910.10 & 2910.70 & 2912.40 & 2912.92 & 2924.69 & 2910.04 \\
\hline
\end{tabular}

Abbreviations: MG - Miscanthus giganteus, W - willow, RCG - reed canary grass, PV - Panicum virgatum, TR - transport routes, S2 - scenario 2 total impact

\section{Conclusions}

Lesaffre Polska S.A. is an example of an environmentally friendly company. In the last 10 years the company made a series of modernizations, which had a huge impact on reducing the influence of the plant on the environment, as well as contributed to the increase in employees' environmental awareness. It should be emphasized that within the introduction of eco-innovations, the financial benefits for the company bring and contribute to building a positive image of the company. In addition, the numerous measures were taken by an environmental company that cultivates and utilizes various species of energy crops for the purpose of obtaining the green energy. The assessment of the most recent investment, a biomass fired steam boiler, has confirmed the environmental orientation of its activities and has shown the significance of changing its biomass use scenario with respect to the decrease of environmental pressures. The investment has proved to be the turning point of the biomass use related emissions. Resigning from co-firing biomass with coal in power plant and combustion it in steam boiler has lowered the emission to almost $20 \%$ of their present level.

All the other factors, contributing to the life cycle impacts of biomass use, have almost negligible effect on its overall impact in comparison to co-firing biomass with coal and related emissions. On the other hand, the complex reengineering of the company biomass use system does not make all these other factors more influential while the environmental impact is concerned. This set of factors includes transport of biomass, its cultivation and processing.

\section{References}

[1] Rodziewicz T, Teneta J, Zaremba A, Wacławek M. Analysis of solar energy resources in Southern Poland for photovoltaic applications. Ecol Chem Eng S. 2012;20(1):177-198. DOI: 10.2478/eces-2013-0014. 
[2] Królczyk J, Rezwiakow A, Tukiendorf M. Mixing of biomass and coal in a static mixer as an example of technological solutions involving implementation of renewable energy. Ecol Chem Eng S. 2014;21(4):685-696. DOI: 10.1515/eces-2014-0050.

[3] Directive of the European Parliament and Council Directive 2009/28/EC of 23 April 2009. On the promotion of the use of energy from renewable sources and amending and subsequently repealing Directives 2001/77/WE and 2003/30/WE (Dz.Urz L140, 05/06/2009 P. 0016-0062). http://eur-lex.europa.eu/legalcontent/en/ALL/?uri=CELEX\%3A32009L0028.

[4] Ericsson K, Nilsson LJ. Assessment of the potencial biomass a supply in Europe using a resources focused approach. Biomass Bioenergy. 2006;30:1-15. DOI: 10.1016/j.biombioe.2005.09.001.

[5] Bernedes G, Hoogwijk M, Richard Van den Broek R. The contribution of biomass in the future global energy supply a review of 17 studies. Biomass Bioenergy. 2003;(25):1-28. DOI: 10.1016/S0961-9534(02)00185-X.

[6] Beringer T, Lucht W, Schaphoff S. Bioenergy production potential of global biomass plantations under environmental and agricultural constraints. GCB Bioenergy. 2011;3(4):299-321. DOI: 10.1111/j.1757-1707.2010.01088.x

[7] Jachniak E, Holubčik M. Characteristics of pellets made from different plant materials. Proc ECOpole. 2015;9(1):95-101. DOI: 10.2429/Proc.2015.9(1)012.

[8] Biomass. Green Energy for Europe. European Commission, D-G for Research Sustainable Energy Systems, 2005. https://ec.europa.eu/research/energy/pdf/biomass_en.pdf.

[9] Polityka energetyczna Polski do 2030 roku. Załącznik do uchwały nr 202/2009 Rady Ministrów z dnia 10 listopada 2009 (Polish Energy Policy until 2030, Annex to Resolution No. 202/2009 of the Council of Ministers 10 November 2009). http://www.me.gov.pl/files/upload/8134/ Polityka\%20energetyczna\%20ost.pdf.

[10] Demirbas A. Combustion characteristics of different biomass fuel. Prog Energy Combust Sci. 2004; 30(2):219-230. DOI: 10.1016/j.pecs.2003.10.004.

[11] Jenkins BM, Baxter LL, Miles Jr. TR, Miles TR. Combustion properties of biomass. Fuel Process Technol. 1998;54:17-46. DOI: 10.1016/S0378-3820(97)00059-3.

[12] Samomssa I, Nono Y, Kamga R. Energy potential of waste derived from some food crop products in the northern part of Cameroon. Int $J$ Energy Power Eng. 2015;4(6):342-352. DOI: 10.11648/j.ijepe.20150406.13.

[13] Nussbaumer T. Combustion and co-combustion of biomass: fundamentals, technologies, and primary measures for emission reduction. Energy Fuels. 2003;17(6):1510-1521. DOI: 10.1021/ef030031q.

[14] Baxter L. Biomass-coal co-combustion: opportunity for affordable renewable energy. Energy Fuels. 2005;84(10):1295-1302. DOI: 10.1016/j.fuel.2004.09.023.

[15] Krzywański J, Rajczyk R, Bednarek M, Wesołowska M, Nowak W. Gas emissions from a large scale circulating fluidized bed boilers burning lignite and biomass. Fuel Process Technol. 2013;116:27-34. DOI: 10.1016/j.fuproc.2013.04.021.

[16] Parikka M. Global biomass fuel resources. Biomass Bioenergy. 2004;27:613-620. DOI: 10.1016/j.biombioe.2003.07.005.

[17] Hellen MC, Keoleian GA, Volk TA. Life cycle assessment of a willow bioenergy cropping system. Biomass Bioenergy. 2003;25:12-14. DOI: 10.1016/S0961-9534(02)00190-3.

[18] Randolph J. Enviromental Land Use Planning and Management. Washington: Island Press; 2004. ISBN13: 9781559639484.

[19] Plan Zagospodarowania Przestrzennego Województwa Opolskiego. Załącznik nr 1 do Uchwały nr XLVIII/505/2010 Sejmiku Województwa Opolskiego z dnia 28 września 2010 (Spatial Development Plan of the Opole Province. Appendix No.1 to the Resolution No. XLVIII /505/2010 of the Opole Regional Assembly of September 28,2010). http://dobryporod.opolskie.pl/serwis/index.php?id=3179.

[20] Jolliet O, Saade-Sbeih M, Shaked S, Jolliet A, Crettaz P. Environmental Life Cycle Assessment. Boca Raton FL: CRC Press; 2015. ISBN: 9781439887660.

[21] Baden-Fuller C, Morgan M. S. Business models as models. Long Range Plan. 2010;43:156-171. http://www.businessmodelcommunity.com/fs/Root/8jig2-businessmodelsasmodels.pdf.

[22] Lewandowska A. Environmental life cycle assessment as a tool for identification and assessment of environmental aspects in environmental management systems (EMS) part 1: methodology. Int J Life Cycle Assess. 2011;16:178-186. https://doi.org/10.1007/s11367-011-0253-2.

[23] López-Bellido L, Wery J, López-Bellido RJ. Energy crops: Prospects in the context of sustainable agriculture. Eur J Agron. 2014;60:1-12. DOI: 10.1016/j.eja.2014.07.001.

[24] Khorshidi Z, Ho MT, Wiley DE. The impact of biomass quality and quantity on the performance and economics of co-firing plants with and without $\mathrm{CO}_{2}$ capture. Int $\mathbf{J}$ Greenhouse Gas Control. 2014;21:191-202. DOI: 10.1016/j.ijggc.2013. 12.011. 
[25] Schakel W, Meerman H, Talaei A, Ramírez A, Faaij A. Comparative life cycle assessment of biomass co-firing plants with carbon capture and storage Appl Energy. 2014;131:441-467. DOI: 10.1016/j.apenergy.2014.06.045.

[26] Kabir R, Kumar A. Bioresource technology comparison of the energy and environmental performances of nine biomass/coal co-firing pathways. Bioresour Technol. 2012;124:394-405. DOI: 10.1016/j.biortech.2012.07.106.

[27] Andric I, Corre O Le, Jamali-Zghal N, Santarelli M, Lacarri B. Environmental performance assessment of retro fitting existing coal fi red power plants to co-firing with biomass: carbon footprint and energy approach. J Cleaner Prod. 2015;103:13-27. DOI: 10.1016/j.jclepro.2014.08.019.

[28] Goglio P, Owende PMO. Research Note: IT Information Technology and the Human Interface A screening LCA of short rotation coppice willow (Salix sp.) feedstock production system for small-scale electricity generation. Bioprocess Biosyst Eng. 2009;103(3):389-394. DOI: 10.1016/j.biosystemseng.2009.03.003.

[29] Nian V. The carbon neutrality of electricity generation from woody biomass and coal, a critical comparative evaluation Intergovernmental Panel on Climate Change. Appl Energy. 2016;179:1069-1080. DOI: 10.1016/j.apenergy.2016.07.004.

[30] Murphy F, Sosa A, Mcdonnell K, Devlin G. Life cycle assessment of biomass-to-energy systems in Ireland modelled with biomass supply chain optimisation based on greenhouse gas emission reduction. Energy Fuels. 2016;109:1040-1055. DOI: 10.1016/j.energy.2016.04.125.

[31] Dahiya A. Bioenergy. Biomass to Biofuels. Cambige: Academic Press; 2015. ISBN: 9780124079090.

[32] Tonini D, Astrup T. LCA of biomass-based energy systems: A case study for Denmark. Appl Energy. 2012;99:234-246. DOI: 10.1016/j.apenergy.2012.03.006.

[33] Tonini D, Hamelin L, Alvarado-Morales M, Fruergaard T. Bioresource technology GHG emission factors for bioelectricity, biomethane and bioethanol quantified for 24 biomass substrates with consequential life-cycle assessment. Bioresour Technol. 2016;208:123-133. DOI: 10.1016/ j.biortech.2016.02.052.

[34] González-García S, Iribarren D, Susmozas A, Dufour J, Murphy RJ. Life cycle assessment of two alternative bioenergy systems involving Salix spp. biomass: Bioethanol production and power generation. Appl Energy. 2012;95:111-122. DOI: 10.1016/j.apenergy.2012.02.022.

[35] www.lesaffre.pl/firma/odpowiedzialnosc-spoleczna (access: 1 April 2016).

[36] Ociepa-Kubicka A, Nitkiewicz T, Karamon B. Ecological actions of company in the range of energy generation from biomass. Proc ECOpole. 2016;10(1):239-246. DOI: 10.2429/proc.2016.10(1)026.

[37] Nag P.K. Power Plant Engineering. New Delhi: Tata McGraw-Hill Publishing Company Limited; 2008. ISBN13: 9780070648159.

[38] Goedkoop MJ, Heijungs R, Huijbregts MAJ, De Schryver AM, Struijs J, Van Zelm R. ReCiPe 2008: A life cycle impact assessment method which comprises harmonised category indicators at the midpoint and the endpoint level; First edition Report I: Characterisation. 6 January 2009, http://www.lcia-recipe.net.

[39] Śliwińska A. State of the art on allocation in LCA and proposals for changes in ISO 140044. Eng Prot Environ. 2017:20(1):97-119. DOI: 10.17512/ios.2017.1.8. 